\title{
Tourist Perception Toward Central Market in Malaysia
}

\author{
Vitra Yunesa ${ }^{1}$ and Nur Atirah Binti Ab Rahim² \\ 1) Graduate Student of Geography Education, Universitas Negeri Padang, Indonesia \\ e-mail: vitrayunesa17@gmail.com \\ 2) Student of Geography, Malaya University, Malaysia \\ e-mail: nuratirahrahim90@gmail.com
}

*Corresponding Author, Received: September 14, 2018, Revised: October 21, 2018, Accepted: December 05, 2018

\begin{abstract}
The purpose of this research is to describe tourist perception toward Central Market in Malaysia, in terms of tourist perception toward Central Market existence, tourist perception toward shopping security in the Central Market, and tourist perception toward shopping convenience in the Central Market. This research employs descriptive qualitative method. Data were collected through observation, interview, and documentation study. Data were analysed by using data reduction stage, data presentation, and drawing conclusion. Research results were 1) Tourist perception toward the existence of Central Market was Central Market as a historical market, Malaysian culinary and souvenir shopping centre, 2) Tourist perception toward shopping security were security official, Security Counter, CCTV and security facilities. 3) Tourist perception toward convenience in the term of facility to facilitate tourist to shop.
\end{abstract}

Keywords: Perception, Tourist, Existence, Convenience, Security

\section{Introduction}

Malaysia is a multicultural country which consists of three main cultures namely malay, china and india. The population is 28.250.500 in total for which 14.379 .900 are males and the rest 13.870 .600 are females. The legitimate religions are islam, buddha, hindu, and christian (Shafaei and Mohamed, 2015). Malaysia is one of the world tourist destinations. Global Muslim Travel Index (2017) stated that Malaysia won the first place as a halal tourist destination, the growth of tourism in Malaysia signified a positive improvement. The number of tourist visited in 2017 reached 82,5 millions of people. Tourism sector plays a huge role toward economic growth in particular country particularly through tourist attractions namely uniqueness, beauty, values such as natural diversity, culture, and man-made products which all becoming the aim of tourist visits (Setianda and Andadari, 2015; Hermon, 2016a). Umar, (2015) revealed goverment and society have to work together developed disctric tourist industy. Hermon (2010); Hermon (2012); Hermon (2015), revealed changes form land cover into land settlement, land industry, market in city must watched sustainable development. 


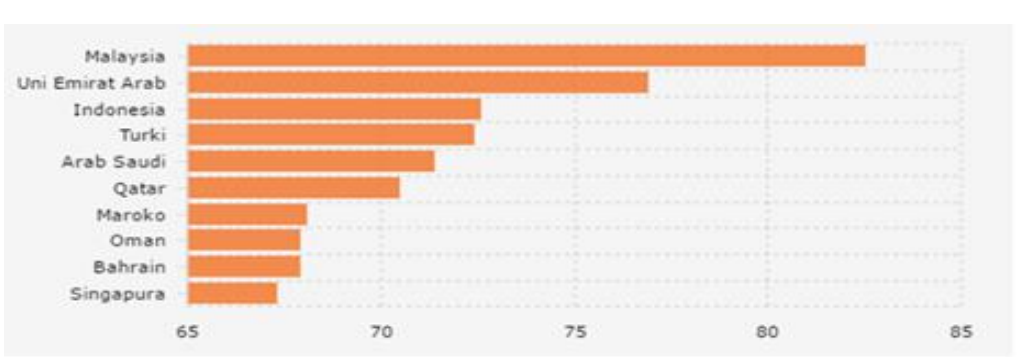

Figure 1. Country with the Highest Score According to Global Muslim Travel Index 2017

Sarbaini et.al (2015); Hermon (2016b); Hermon (2017) revealed that tourist perception is heavily influenced by individual subjectivity. Each person possesses a different perception toward the same object. Moreover, Kurniawati (2016); Hermon et al (2018) mentioned that tourist perception can be one of the benchmark measurements of a tourist site quality. Tourist is an individual or a group of people who do tourism activities (Fitroh et.al., 2017). Normally, tourists come to Malaysia to visit its great various tourism sites in terms of natural beauty, and specific culture such as Caves Stone, Sri Mariamman Temple, Bird Park of Kuala Lumpur, Bukit Bintang, Kek Lok Si Temple, Twin Tower of Malaysia, Lake Gardens, and tourist also find it interesting to visit shopping site like Central Market. Central Market is one of art market which also act as a public facility and tourism site of a city attached with social, commercial as well as educational functions in order to express activities and city lifestyle and society which becoming the identity and to distinguish one particular city with another. Central Market is located on street Hang Katsuri, 50050 Kuala Lumpur, Malaysia. It was established in 1888 as a wet market. Central Market called as the inheritance site by Malaysia Heritage Society. The purpose of this research is to describe tourist perception toward Central Market in Malaysia in terms of tourist perception toward Central Market existence, tourist perception toward shopping security in the Central Market, and tourist perception toward shopping convenience in the Central Market.

\section{Method}

This is a descriptive qualitative research (Hermon et al.., 2018). The research location is at Central Market Malaysia. Data were collected through observation, interview and documentation study. Both primary and secondary data were employed in this research. Primary data is the result of the interview with informant such as tourist who visited Central Market and society in the research location. Secondary data is the library data which consists of book, scientific journal, and article in both print and electronic papermedia and other closely related literature with the main problem in this research, which might be able to help to analyse and to comprehend primary data (Triningsih, 2013). Data analysis techniques were data reduction stage, data display and drawing conclusion (Agustin, 2017).

\section{Results and Discussion}

\section{Tourist Perception Toward Central Market Existence}

Existence is derived from Latin word Existere, exmeans exit and sitere means exist. Existence emphasizes that something is exist or the existence of a presence with a defence element. Existence means not stiff and not stagnant. It is flexible and experiences progression, stagnant or decline. Market existence is the presence of Central Market as a market, public space as well as tourism site which consist of defence element and acknowledge by other party. The market existence continuity indicator can be seen from tourist interest or tourist preference in shopping. Tourist perception influenced by one's perception such as situation, need, willing and one's willing to take a risk or decision factors (Andriani and Ali, 2013).

The existence of Central Market can be seen by its excellence namely: First, Central Market as a historic market according to the interview with Madam Siti on 7 July 2018. She is a janitor in the Central Market. She revealed that: "Pasar telah lama berdiri sejak tahun 1888, sejak zaman Inggeris menyerbu 
Malaysia." In the other words, the market has existed since 1888 since UK colonized Malaysia". It can be concluded that central market is a historic market since it has existed for over 130 years until now on. Madam Goda who is a tourist from India on 8 July 2018 on an interview says:"this market is an interesting, unique and historic shopping center, so I'm interested in going here". Hence, the existence of central market can be seen from the history and its development as an attraction to the tourist.

Central Market is a traditional market which has established since the colonization of UK. This market was established by Yap Ah Loy which is located on Hang KasturiStreet. This market is originally a wet market to sell household needs such as fruits, fish and vegetables. The improvement of the art market building keep took place in 1889, 1895, 1920 and 1921. In 1970, there occurred a rebellion between Heritage Society Malaysia and the government who wants demolition of Central Market to build a skyscraper tower, Dayabumi. The rejection shown by Heritage Society Malaysia experiencing success in 1985. On 15 April 1986, the art market was officially opened as a Central Market Heritage, Art, and Craft which has numerous stalls and kiosks and trades various kinds of art product that can be used as a souvenir. Kasturi Nursery Walk in 2011 is one form of development which aimed to provide convenience to the tourist who wants to shop outside of the Central Market building.

Second, Malaysian specific culinary and souvenir centre which sells various kinds of accessories, local chocolate product, antique product and craft and etc, with more than 350 small shops with a bazaar concept. In the west side of the building there are Malay straits, Chinese straits and Indian straits. In the second floor, there are shops that are selling clothes like Malaysian batik and Malaysian culinary such as lemak rice, kerabu rice, kendarrice, karipap, Umaiculinary, kolok noodle culinary and the like. At the back of the art market, there also Annexe Gallery which provides various kinds of paintings. The selling and buying transaction activities lasted from 10.00 in the morning to 22.00 in the night.

Third, the cleanliness in the Central Market is good as indicated by the absence of piles of rubbish scattered all over the Central Market. The market manager has provided cleaning service, cleaning facility such as rubbish bin and the implementation of cleaning regulation along with the high awareness of the society and the visitor to keep the art market stay clean.

Fourth, the accessibility in the Central Market is well supported with the road infrastructure such as pavement, concrete road, road sign, wide and broad road and line for pedestrians. The accessibility is also supported with public transportation to facilitate tourist to visit Central Market. Train and bus are the public transportation that can be used. Next, the train station and bus station is located around the Central Market.

Fifth, there are many recreation facilities inside the Central Market. The facility was developed to attract the tourist. The facilities are Fish spa, 3D pictures. Massage, DIY batik painting, henna, caricature. These recreational facilities were supported by government and the central market manager as can be seen from the brochure containing information and central market excellence such as central market historic information, train map of Kuala Lumpur, emergency number information, culinary centre information, tourism sites information which are located closely to central market namely Petaling Street, Lebuh Ampang (Little India), Guan Di Temple, Sri Mahamariamman Temple, Masjid Jamek, Sultan Abdul Samad Building, KL Bird Park, The National Mosgue.

\section{Tourist Perception toward Shopping Security in Central Market}

Security is a safe situation or someone or a group of people tranquility toward the risk caused by the possible dangers, a situation called unsecure on conditions like theft, mugging, moping and other criminal practices, so that the visitors found unsecure, and feel afraid of and resulted in reluctance to visit places which are not secure (Suharto, 2016).

The researcher held an interview on 11 July 2018 with an informant called Sofi who is a tourist from Indonesia. She says that "Saya merasa aman jika berbelanja di sini, terlihat banyak petugas keamanan yang berkeliling, ada CCTV. The result of the interview shows the availability of some security platforms such as CCTV and the existence of security guard. These may lead to the safety feeling of the tourist when shopping in central market. 
The tourist perception toward shopping security in the Central Market can be seen from many indicators such as (1) The availability of the security guard, there are two kinds of security guards, namely help police and nepal police who are in charge of in the entrance in the Central Market. (2) The availability of security counter in the Central Market. (3) The use of CCTV to record and observe the security in the Central Market. (4) The availability of security facilities which can be used as a first step in the event of an accident such as telephone to the fire fighter as an alarm in the event of a fire, fire extinguishers, and fire hose reels to shoot fore down, evacuation line and emergency stairs. Tourist perception toward security in the Central Market is good; however security improvement is of vital importance to overcome the crimes.

\section{Tourist Perception toward Shopping Convenience in Central Market}

Convenience is the result of pleasure and happiness during shopping, not after the shopping process done. The visitor who feel the convenience in shopping might have a higher probability to be engaged in further shopping activity (Mahkota et.al., 2014). Both tourist security and convenience are an absolute condition for the tourism sector to experience feelings of pleasure without necessarily worrying during the trip. Unsecure and inconvenience tourism sites may harm tourist physically and financially (Fanani and Pangestuti, 2017).

Tourist perception toward Central Market relies heavily on senses and experiences to the Central Market itself. Permadi et.al (2018) said that perception is one's cognitive process in interpreting, negotiating, give meaning and comprehend information about the environment through five senses. Tourist perception is influenced by both internal and external factors. Internal factor originated from the tourist himself such as feeling, attitude, motivation which directly or indirectly becomes one of consideration in perceiving something. The target of the perception (can be in the form of person, thing, or event) is based on the consideration toward obtained information related with the products sold, price through promotion (brochure) in the art market in which later will be harmonized with goods needed by tourist as proposed by Dwiputra (2013).

The researcher conducted interview on 11 July 2018 toward many tourists in the central market. One of the tourists, Steven (originated from UK) on 11 July 2018 says that: "I am very comfortable shopping at the central market, traders and friendly people, stalls and kiosks are neatly arranged." It can be concluded that most of the tourists feel convenience shop in the Central Market due to some excellences in improving tourist convenience. The excellences would be described descriptively below.

Tourist perception toward shopping convenience in the Central Market was influenced by the good stimulation from Central Market. The stimulation is related with: (1) facility availability such as parking lot, place of worship and toilet (based on sexes), ATM, (2)the availability of information center in the main entrance, (3) friendliness showed by the merchant tothe visitor of the Central Market (4) stalls and kiosks in a neat and tidy arrangement, (5) regulation of smoking prohibition in the market and the availability of special room for smoking, (6) the appropriate air ventilation and lighting.

\section{Conclusion}

The researcher concludes that tourist perception toward central market in the terms of central market existence, shopping security, and shopping convenience. Tourist perception toward central market existence was central market is a historic market, Malaysian culinary shopping and souvenir shopping, cleanliness, accessibility, and recreational facility were all market excellences, hence the market can still survive and demanded by the tourist particularly foreign tourist. Tourist perception toward shopping security is the existence of security guard, Secutiry Counter, CCTV, and security facilities. Tourist perception toward shopping convenience is the parking lot facility, worship facility, ATM, rest room, the availability of information center, the friendliness of the merchant, neat and tidy arrangement of the stalls and kiosks, particular room for smoking, appropriate air ventilation and lighting. 


\section{References}

Agustin, A. 2017. Persepsi Masyarakat terhadap Penggunaan Transportasi Online (GO-JEK) di Surabaya. Jurnal Ilmu dan Riset Manajeman Volume 6, Nomor 9, September 2017 ISSN:2461-0593.

Andriani, M. N and M. M. Ali. 2013. Kajian Eksistensi Pasar Tradisional Kota Surakarta. Jurnal Teknik PWK Volume 2 Nomor 2 2013, Hal 252-269.

Dwiputra, R. 2013. Preferensi Wisatawan terhadap Sarana Wisata di Kawasan Wisata Alam Erupsi Merapi. Jurnal Perencanaan Wilayah dan Kota, Vol. 24 No. 1, April 2013 Hlm. 35-48.

Fanani, Z and E. Pangestuti. 2017. Analisis Keamanan dan Kenyamanan Objek Wisata Penanjakan 1 Bromo. Jurnal Administrasi Bisnis (JAB). Vol 49 No.2 Agustus 2017.

Fitroh, S. K. A. et.al. 2017. Pengaruh Atraksi Wisata dan Motivasi Wisatawan Terhadap Keputusan Berkunjung (Survei Pada Pengunjung Wisata Kawah Ijen). Jurnal Administrasi Bisnis Vol. 42 No. 2 Januari 2017.

Hermon, D., Khairani., Daswirman., S. Karim., Dasrizal., and Triyatno. 2008. Metode dan Teknik Penelitian Geografi Tanah: Aplikasi Instrumen dan Acuan Penelitian Geografi Fisik. Yayasan Jihadul Khair Center.

Hermon, D. 2010. Geografi Lingkungan: Perubahan Lingkungan Global. UNP Press.

Hermon, D. 2012. Mitigasi Bencana Hidrometeorlogi: Banjir, Longsor, Degradasi Lahan, Ekologi, Kekeringan, dan Puting Beliung. UNP Press. Padang.

Hermon, D. 2015. Geografi Bencana Alam. Jakarta: PT RajaGrafindo Persada.

Hermon, D. 2016a. The Strategic Model of Tsunami Based in Coastal Ecotourism Development at Mandeh Regions, West Sumatera, Indonesia.Journal of Environment and Earth Science. Volume 6.

Hermon, D. 2016b. Mitigasi Perubahan Iklim. Rajawali Pers (Radjagrafindo).

Hermon, D. 2017. Climate Change Mitigation. Rajawali Pers (Radjagrafindo).

Hermon, D., Y. Suasti., Ernawati., Afdhal., and H. Edial. 2018. Geografi: Geografi untuk SMU. Jurusan Geografi Universitas Negeri Padang.

Kurniawati, R. 2016. Persepsi Wisatawan Terhadap Atraksi Wisata Animal Watching di Taman Nasional Komodo. Jurnal Destinasi Kepariwisataan Indonesia Vol. 1 No, 1 Juni 2016.

Mahkota, A. P et.al. 2014. Pengaruh Kepercayaan dan Kenyamanan terhadap Keputusan Pembelian Online (Studi Pada Pelanggan Website Ride Inc). Jurnal Administrasi Bisnis (JAB) Vol.8 No.2 Maret 2014.

Permadi, L. A et.al. 2018. Persepsi dan Sikap Masyarakat Terhadap Rencana Dikembangkannya Wisata Syariah (Halal Tourism) di Provinsi Nusa Tenggara Barat. Amwaluna. Vol. 2, No. 1 (Januari, 2018). Hal 39-57. ISSN 2540-8399.

Sarbaini et.al. 2015. Persepsi Masyarakat Terhadap Partai Politik di Desa Terantang Kecamatan Mandastana Kabupaten Barito Kuala. Jurnal Pendidikan Kewarganegaraan: Volume 5, Nomor 9, Mei 2015.

Setianda, V and R. K. Andadari. 2015. Menimbang Daya Saing Pariwisata Indonesia (Dibandingkan Singapura, Malaysia dan Thailad). Jurnal Manajeman Bisnis Indonesia Vol 2 No. 3 Juni 2015.

Shafaei, F and B. Mohamed. 2015. Malaysia's Branding as an Islamic Tourism Hub. an Assessment. Malaysia Journal of Society And Space 11 Issue 1 (97-106) 2015, ISSN 2180-2491.

Suharto. 2016. Studi Tentang Keamanan dan Keselamatan Pengunjung Hubungannya dengan Citra Destinasi (Studi Kasus Gembira Loka Zoo). Jurnal Media Wisata. Volume 14, Nomor 1, Mei 2016.

Triningsih, A. 2013. Masalah Demografis dan Kebijakan Pemerintah Provinsi Kepulauan Riau. Jurnal Kependudukan Indonesia. Vol. 8, No 2 Tahun 2013 ISSN 1907-2902.

Umar, I. 2015. Analisis Potensi Pengembangan Ekowisata Pantai Mandeh Kabupaten Pesisir Selatan. Jurnal Spasial. p-ISSN : 2540-8933, e-ISSN : 2541-4380. 